\title{
Analisis Pendapatan Usahatani Selada Air di Desa Popnam, Kecamatan Noemuti, Kabupaten Timor Tengah Utara
}

Febronius Nana ${ }^{\mathrm{a}}$, Simon Juan Kune ${ }^{\mathrm{b}}$, dan Adeline Norawati Hutapea

${ }^{a}$ Fakultas Pertanian, Universitas Timor, Kefamenanu, TTU - NTT, Indonesia.

${ }^{b}$ Fakultas Pertanian, Universitas Timor, Kefamenanu, TTU - NTT, Indonesia.

${ }^{c}$ Fakultas Pertanian, Universitas Timor, Kefamenanu, TTU - NTT, Indonesia.

\section{Article Info}

\section{Article history:}

Received in revised form 4 Januari 2018

\section{Keywords:}

Pendapatan

Usahatani

Selada Air

Popnam
Received 8 Desember 2017

Accepted 11 Januari 2018

\begin{abstract}
Abstrak
Desa Popnam adalah salah satu desa di kecamatan Noemuti, kabupaten TTU yang masyarakatnya mengembangkan usahatani selada air yang berjalan secara turun temurun karena wilayah ini memiliki kondisi alam yang mempunyai potensi sumber air dan lahan pertanian yang cocok untuk membudidayakan selada air. Penelitian ini bertujuan untuk mengetahui 1) gambaran umum usahatani selada air; 2) pendapatan yang diperoleh dari usahatani selada air; dan 3) keuntungan relatif yang diperoleh dari usahatani selada air di desa Popnam, kecamatan Noemuti, Kabupaten TTU. Penelitian dilaksanakan di desa Popnam, kecamatan Noemuti, Kabupaten TTU, pada bulan April sampai November 2017. Populasi berjumlah $342 \mathrm{KK}$ dengan sampel berjumlah 50 petani yang ditentukan mengounakan metode purposive sampling. Untuk mengetahui gambaran umum usahatani selada maka digunakan metode analisis deskriptif kualitatif, untuk mengetahui pendapatan usahatani maka dilakukan analisis pendapatan sedangkan untuk mengetahui keuntungan relatif dari usahatani selada digunakan analisis R/C Rasio. Hasil penelitian menunjukkan Lahan usahatani yang digarap oleh petani adalah lahan milik sendiri dengan kisaran luas lahan bervariasi antara 3-15 are. Tahapan kegiatan usahatani dimulai dari persiapan lahan, persiapan bibit, penanaman, pemeliharaan (penyiangan, pemupukan dan pengendalian hama penyakit), panen dan pasca panen. Pendapatan usahatani selada air di desa Popnam adalah sebesar Rp201.724.000,00 dengan rata-rata pendapatan usahatani selada air sebesar Rp4.034.480,00. Nilai R/C Ratio sebesar 7,103. Artinya kegiatan usahatani selada air di desa Popnam menguntungkan secara ekonomis dan layak untuk dilanjutkan karena setiap biaya yang dikeluarkan sebesar Rp1,00 akan memberikan penerimaan sebesar Rp7,103,00. ()2018 dipublikasikan oleh Agrimor.
\end{abstract}

\section{Pendahuluan}

Kabupaten Timor Tengah Utara (TTU) merupakan salah satu kabupaten di Indonesia yang sebagian masyarakat berusahatani sayur-sayuran selain tanaman pangan untuk memenuhi kebutuhan hidup. Selain untuk dikonsumsi, berbagai penelitian terdahulu telah membuktikan bahwa usahatani sayur-sayuran di kabupaten TTU juga menguntungkan secara ekonomi dan memberikan pendapatan tambahan bagi petani, seperti usahatani sawi di desa Humusu Oekolo (Nubatonis, 2016), atau di kelurahan Oelami (Opat \& Hutapea, 2017). Selain sawi, usahatani kangkung di kelurahan Bansone (Tani’i \& Kune, 2016) dan usahatani cabe rawit merah di desa Tapenpah (Haki \& Taena, 2017) juga dinyatakan layak dikembangkan karena menguntungkan secara ekonomi. Salah satu jenis sayur yang diusahakan oleh petani di kabupaten TTU adalah selada air.

Selada air (Nasturtium Officinale) adalah tumbuhan menahun yang cepat tumbuh, bersifat akuatik atau semi akuatik, asli Eropa dan Asia. Tumbuhan in adalah salah satu dari sayuran daun tertua yang dikonsumsi manusia (Priyadi, 2007). Selada air sangat mudah tumbuh dan sering ditemukan tumbuh liar di aliran sungai kecil, kolam, rawa, atau bagian danau yang dangkal (Muhlisah \& Sapta, 1997). Selada air kaya vitamin A dan mengandung banyak vitamin K bersama dengan sejumlah antioksidan karotenoid dan phyochemical pelindung. Nutrien di dalam selada air mencegah kangker dan macular degeneration, membantu membangun sistim imun, dan mendukung kesehatan tulang. Zat besi membantu sel-sel darah merah membawa oksigen ke jaringan tubuh untuk energi (Pangkalan Ide, 2014)

Desa Popnam adalah salah satu desa di kecamatan Noemuti, kabupaten TTU yang masyarakatnya mengembangkan usahatani selada air yang berjalan secara turun temurun. Desa Popnam khususnya dusun Oe'Meu memiliki kondisi alam yang mempunyai potensi sumber air dan lahan pertanian yang cocok untuk membudidayakan selada air. Selada darat telah lama dibudidayakan oleh petan desa Popnam akan tetapi awalnya bersifat sub sistem atau untuk memenuh kebutuhan konsumsi keluarga. Dengan berjalanya waktu secara perlahan-lahan jenis sayuran ini memiliki nilai ekonomis, permintaan akan komoditi sayuran lokal yang meningkat sehingga para petani tidak hanya menanam untuk memenuhi kebutuhan keluarga saja tetapi juga bersifat komersial.

Berdasarkan survei awal, produksi selada di desa Popnam tahun 2012-2016 adalah 9.600 ikat (diameter ikatan $+3-4 \mathrm{~cm}$ ) pada tahun 2012, 14.400 ikat pada tahun 2013, 28.800 ikat pada tahun 2014, 48.000 ikat pada tahun 2015 dan 72.000 ikat pada tahun 2016. Data menunjukkan bahwa produksi selada air selalu mengalami peningkatan setiap tahun. Pemasaran pada umumnya masih terbatas di daerah sekitar sentra produksi seperti Pasar Baru dan Pasar Lama Kefamenanu tetapi mulai berkembang ke daerah lain seperti Atambua dan Betun. Dengan letak kabupaten TTU yang berada di tengah pulau Timor, maka komoditi sayuran berpeluang untuk dipasarkan di berbagai kabupaten hingga ke Kupang sebagai ibu kota provinsi. Penelitian Pay \& Nubatonis, (2017) membuktikan bahwa komoditi buncis yang diproduksi di desa Oerinbesi kabupaten TTU telah dipasarkan hingga konsumen yang berada di Kupang.

Penerimaan usahatani selada air digunakan untuk memenuhi berbagai kebutuhan rumah tangga, kebutuhan anak sekolah dan kebutuhan untuk mengembangkan usahataninya, meskipun demikian belum dapat dijelaskan besar pendapatan petani setiap musimnya yang bersumber dari usahatani selada air, untuk itu perlu dilakukan kajian dengan topik "Analisis Pendapatan Usahatan Selada Air di desa Popnam, kecamatan Noemuti, kabupaten TTU". Penelitian in bertujuan untuk mengetahui 1) gambaran umum usahatani selada air; 2) pendapatan yang diperoleh dari usahatani selada air; dan 3) keuntungan relatif yang diperoleh dari usahatani selada air di desa Popnam, kecamatan Noemuti, Kabupaten TTU.

\section{Metode}

Penelitian dilaksanakan di desa Popnam, kecamatan Noemuti, Kabupaten TTU, pada bulan April sampai November 2017. Populasi dalam penelitian in adalah semua petani di desa Popnam, kecamatan Noemuti yang mengusahakan selada yang berjumlah $342 \mathrm{KK}$. Teknik pengambilan sampel yang digunakan adalah purposive sampling yaitu metode pemilihan sampel berdasarkan atas ciriciri atau sifat populasi yang sudah diketahui sebelumnya yang dilakukan sesuai petunjuk Sutrisno, (2004) sehingga sampel yang diambil $50 \mathrm{KK}$ dengan kriteria responden sudah mengusahakan selada air selama lima tahun atau lebih.

Data yang digunakan dalam penelitian ini adalah data primer yang diperoleh dengan teknik wawancara langsung dengan responden atau petani pengusaha selada air di lokasi penelitian berdasarkan daftar pertanyaan yang disiapkan oleh peneliti sedangkan data sekunder diperoleh dari instansi atau lembaga terkait.

Data yang diperoleh dikumpulkan kemudian ditabulasi dan dianalisis berdasarkan tujuan penelitian. Untuk mengetahui gambaran umum usahatani selada maka digunakan metode analisis deskriptif kualitatif sesuai petunjuk (Sugiyono, 2006), sedangkan mengetahui pendapatan usahatani selada air maka dilakukan analisis pendapatan sesuai petunjuk (Soekartawi, 1995), dengan formula:

$$
\begin{aligned}
& \mathrm{Pd}=\mathrm{TR}-\mathrm{TC} \\
& \mathrm{TR}=\mathrm{Py} . \mathrm{Y}
\end{aligned}
$$

$\mathrm{TC}=\mathrm{FRC}+\mathrm{VC}$

Sehingga Pd $=\{[$ Py. Y $] /[$ FC + VC $]\}$ dimana:

$\mathrm{Pd}=$ Pendapatan usahatani selada

Py = Harga sayur selada air

$\mathrm{Y}=$ Produksi yang diperoleh

$\mathrm{FC}=$ Biaya tetap

$\mathrm{VC}=$ Biaya variabel

Untuk mengetahui keuntungan relatif dari usahatani selada digunakan analisis R/C Ratio sesuai petunjuk (Soekartawi, 1993) dengan formula R/C Ratio = Total Penerimaan $/$ Total Biaya dengan kriteria yang digunakan adalah:

$\mathrm{R} / \mathrm{C}>1$ : Secara ekonomis mengalami keuntungan

$\mathrm{R} / \mathrm{C}=1$ : Secara ekonomis usahatani tidak mengalami keuntungan atau kerugian

$\mathrm{R} / \mathrm{C}<1$ : Secara ekonomis usahatani mengalami kerugian.

Perhitungan biaya produksi yang dikeluarkan oleh petani dihitung sesuai petunjuk (Hadisapoetro, 1973).

\section{Hasil dan Pembahasan}

\subsection{Deskripsi Petani Selada Air}

Umur merupakan salah satu faktor yang mempengaruhi produktivitas kerja. Petani selada air di desa Popnam sebagian besar (67\%) berada dalam usia produktif yakni 17 orang atau 34\% berada dalam kisaran umur 27-38 tahun dan 25 orang atau $50 \%$ berada dalam kisaran umur 39-50 tahun. Kisaran umur petani responden dapat dilihat pada Gambar 1.

Petani selada air lebih banyak berpendidikan SD yakni berjumlah 32 orang atau $64 \%$, SMP berjumlah 8 orang atau $15 \%$, SMA berjumlah 6 orang atau $12 \%$ dan petani yang tidak tamat SD berjumlah 4 orang atau $8 \%$. Hal ini menunjukkan bahwa rata-rata pendidikan petani di desa Popnam masih sangat rendah.

Kisaran pengalaman petani responden dalam berusahatani selada air yaitu 5 10 tahun berjumlah 8 orang atau 16\%,11-15 tahun berjumlah 5 orang atau $10 \%$, 16-20 tahun berjumlah 15 orang atau 30\%, 21-25 tahun berjumlah 10 orang atau $20 \%, 26-30$ tahun berjumlah 5 orang atau 10\%, 31-35 tahun berjumlah 5 orang atau $10 \%$ dan yang berpengalaman sama dengan atau lebih dari 36 tahun 
berjumlah 2 orang atau 4\%. Dengan demikian dapat dikatakan bahwa petani di desa Popnam cukup berpengalaman dalam berusahatani selada air.

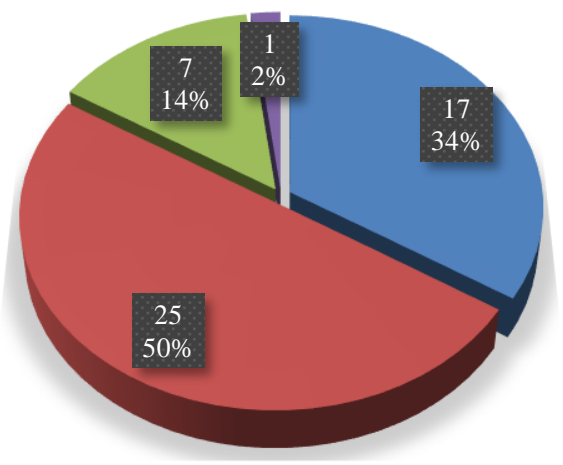

-27-38 Tahun $\square$ 39-50 Tahun $\square$ 51-62 Tahun $\square>62$ Tahun

Gambar 1. Kisaran Umur Petani Selada Air

Sebanyak 41 orang petani atau $82 \%$ memiliki tanggungan keluarga antara 14 orang sedangkan sisanya 9 orang petani atau $18 \%$ memiliki tanggungan keluarga 5-8 orang.

\subsection{Gambaran Umum Usahatani Selada Air}

Tanaman selada air merupakan salah satu komoditi hortikultura yang sejak lama dibudidayakan oleh petani di desa Popnam karena memiliki potensi sumber daya air irigasi dan lahan pertanian yang sangat cocok untuk menanam sayuran jenis ini. Berikut ini adalah tahapan-tahapan budidaya sayur selada air yang meliputi persiapan dan pengolahan lahan, persiapan bahan tanaman, penanaman, pemeliharaan (penyiangan, pemupukan, dan pengendalian hama penyakit), panen dan pasca panen.

a. Persiapan Lahan

Persiapan lahan di lokasi penelitian pada umumnya meliputi pengolahan tanah menggunakan pacul dengan kedalaman 30-40 cm. Selanjutnya tanah diistirahatkan selama \pm 7 hari menjelang penanaman agar sisa-sisa tanaman dan gulma mengalami pembusukan atau penguraian. Tahap akhir dari pengolahan adalah pelumpuran, yang dimaksud dengan pelumpuran yakni bongkahan tanah kemudian dihaluskan sehingga akar tanaman bebas mencari unsur hara. Rata-rata curahan tenaga kerja yang dibutuhkan dalam persiapan lahan sebesar 4,949 HKO.

\section{b. Persiapan Bahan Tanaman}

Bahan tanaman yang digunakan oleh petani selada air adalah stek. Bahan tanaman yang digunakan tidak dibeli karena disediakan sendiri yaitu menanam kembali bagian-bagian sisa panen. Bagian tanaman selada yang digunakan sebagai stek yaitu pangkal batang atau bagian batang yang dekat dengan permukaan tanah dengan ukuran $10-15 \mathrm{~cm}$.

\section{c. Penanaman}

Penanaman dilakukan oleh petani pada setiap bulan setelah tanah diolah. Penanaman yang lazim dilakukan oleh petani dengan cara ditebar, jumlah bibit yang diperlukan disesuaikan dengan kisaran luas lahan. Waktu yang dibutuhkan petani dalam melakukan penanaman maksimal 2 hari. Rata-rata curahan tenaga kerja untuk kegiatan penanaman sebesar 1,08 HKO.

\section{d. Pemeliharaan}

- Pemupukan

Pupuk yang digunakan oleh petani di lokasi penelitian berupa pupuk kimia di antaranya pupuk NPK. Pemberian pupuk dilakukan pada pagi hari atau sore hari dengan cara ditebar dan biasanya pada saat tanaman berumur \pm 7 hari setelah tanam dengan jumlah pupuk yang dibutuhkan sangat bervariasi tergantung kisaran luas lahan, waktu yang diperlukan dalam pemberian pupuk adalah 1 hari. Rata-rata curahan tenaga kerja yang dibutuhkan dalam kegiatan pemupukan sebesar 0,284 HKO.

\section{- Penyiangan}

Pada umumnya, kegiatan penyiangan dilakukan oleh petani di lokasi penelitian satu kali setiap 2 minggu. Penyiangan dilakukan pada rumput yang tumbuh di sekitar tepi pematang dengan cara ditebas menggunakan parang. Ratarata curahan tenaga kerja yang dibutuhkan dalam kegiatan penyiangan sebesar 2,997 HKO.

○ Pengendalian Hama Penyakit

Pengendalian hama penyakit dilakukan 14 hari setelah tanam. Ada 3 jenis pestisida yang biasa digunakan oleh petani selada seperti Biokorn, Villia dan Gibron. Ketiga jenis pestisida dicampur dan diaplikasi pada waktu bersamaan. Rata-rata curahan tenaga kerja yang digunakan pada kegiatan pengendalian hama penyakit sebesar 1,742 HKO. e. Panen dan Pasca Panen

Pemanenan selada pada lokasi penelitian dilakukan pada umur 40 hari setelah tanam dengan cara memetik secara manual dengan menggunakan tangan. Jika terlambat memetik maka batang membengkok ke bawah bahkan menjalar dan batang semakin tua sehingga tidak diminati konsumen. Pasca panen merupakan tahap akhir dari kegiatan usahatani dimana selada yang telah dipetik kemudian diikat menggunakan tali gewang lalu dibungkus menggunakan karung dan siap untuk dipasarkan. Rata-rata curahan tenaga kerja luar keluarga yang dibutuhkan dalam kegiatan panen dan pasca panen sebesar 3,578 $\mathrm{HKO}$.

\subsection{Analisis Pendapatan Usahatani Selada Air}

Untuk menganalisis besarnya pendapatan yang diperoleh dari usahatani selada air maka dijelaskan elemen-elemen penting yang berhubung di antaranya. Luas lahan garapan usahatani sayur selada air oleh para petani responden terbanyak adalah 7-10 are yang digarap oleh 28 orang atau 56\%, 10 orang atau $20 \%$ dengan kisaran luas lahan 3-6 are, 8 orang atau $16 \%$ dengan kisaran luas lahan 11-14 are sedangkan 4 orang atau 8\% dengan luas lahan lebih dari 14 are.

Tenaga kerja usahatani sayur selada di lokasi penelitian berasal dari tenaga kerja dalam keluarga dan tenaga kerja luar keluarga. Kontribusi tenaga kerja dalam keluarga tidak dihitung. Namun, peneliti hanya menghitung biaya konsumsi selama satu kali musim tanam. Alokasi tenaga kerja dalam keluarga dibutuhkan untuk kegiatan persiapan lahan, persiapan bibit, penyiangan, pemupukan, pengendalian hama penyakit. Sedangkan, tenaga kerja luar keluarga hanya dibutuhkan pada saat panen sehingga dihitung dalam biaya. Rata-rata curahan tenaga kerja sebanyak 4,948 HKO karena pada kegiatan persiapan lahan membutuhkan waktu 4-5 hari. Rata-rata curahan tenaga kerja dalam keluarga pada usahatani selada air dapat dilihat pada Gambar 2.

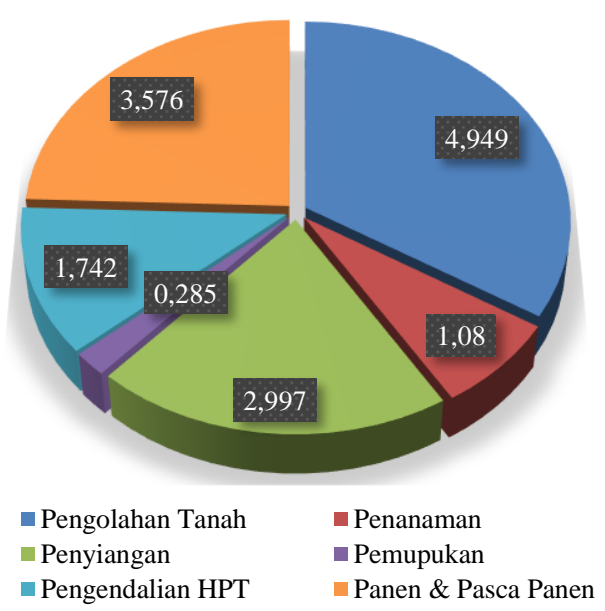

Gambar 2. Curahan Tenaga Kerja Usahatani Selada Air (HKO)

\section{a. Biaya Usahatani Selada Air}

Biaya usahatani sayur selada air adalah seluruh korbanan yang dinilai dengan uang dalam usahatani selada. Komponen-komponen biaya dalam usahatani sayur selada terdiri dari biaya tetap dan biaya variabel.

- Biaya Tetap

Biaya tetap adalah korbanan yang dikeluarkan selama satu kali musim tanam yang besarannya tidak dipengaruhi oleh frekuensi produksi usahatani yang dihasilkan, dinyatakan dalam bentuk rupiah (Uang). Biaya tetap dalam penelitian ini merupakan biaya penyusutan peralatan dan pajak. Penyusutan peralatan dalam penelitian ini dapat dihitung menggunakan metode garis lurus sehingga biaya tetap yang dikorbankan oleh petani desa Popnam sebesar Rp1.895.000,00 dengan rata-rata biaya tetap yang dikeluarkan sebesar Rp37.900,00. Penyusutan alat yang lain dalam penelitian ini tidak dihitung karena tidak dialokasikan secara khusus untuk usahatani sayur selada, yang dihitung hanya pisau, karung dan pajak. Biaya tetap usahatani selada air dapat dilihat pada Tabel 1.

\begin{tabular}{|c|c|c|c|}
\hline $\mathrm{No}$ & Jenis Alat & Total (Rp) & Rerata Biaya (Rp) \\
\hline 1 & Pisau & $946.625,00$ & $18.932,50$ \\
\hline 2 & Karung & $816.000,00$ & $16.320,00$ \\
\hline 3 & Pajak & $132.375,00$ & $2.647,50$ \\
\hline
\end{tabular}

\section{- Biaya Variabel}

Total biaya variabel yang dikeluarkan selama satu kali musim tanam sebesar Rp30.781.000,00 dengan rata-rata Rp615.620,00. Perhitungan biaya variabel tidak disertakan bibit atau stek karena disediakan sendiri oleh petani serta biaya tenaga kerja dalam keluarga tidak dihitung juga karena tenaga kerja berasal dari dalam keluarga, maka yang dihitung adalah biaya konsumsi untuk satu kali produksi. Biaya variabel usahatani selada air dapat dilihat pada Tabel 2. 
Tabel 2. Biaya Variabel Usahatani Selada Air

\begin{tabular}{llrr}
\hline No & Komponen Biaya & \multicolumn{1}{c}{ Total $(\mathrm{Rp})$} & \multicolumn{1}{c}{ Rerata $(\mathrm{Rp})$} \\
\hline 1 & Pupuk & $3.338 .000,00$ & $66.760,00$ \\
2 & Pestisida & $4.760 .000,00$ & $95.200,00$ \\
3 & Transportasi Beli Saprodi & $500.000,00$ & $10.000,00$ \\
4 & Penjualan & $1.360 .000,00$ & $27.200,00$ \\
5 & Panen & $3.325 .000,00$ & $66.500,00$ \\
6 & Konsumsi & $17.498 .000,00$ & $349.960,00$ \\
\hline
\end{tabular}

b. Penerimaan Usahatani Selada Air

Produksi selada air di desa Popnam rata-rata 479 ikat kecil untuk setiap kal musim tanam dengan total produksi sebanyak 23.440 ikat. Pada saat petani menjual, selada air diikat menjadi ikatan-ikatan besar terdiri dari 18 ikat kecil dengan harga per ikat Rp10.000,00 sehingga penerimaan petani selama satu kali musim tanam sebesar Rp234.400.000,00 dengan rata-rata penerimaan sebesar $\mathrm{Rp}$ 4.688.000,00.

\section{c. Pendapatan Usahatani Selada Air}

Pendapatan merupakan selisih antara penerimaan dari usahatani salada air dengan semua biaya selama satu kali musim tanam. Total pendapatan dari usahatani sayur selada air pada 50 petani responden untuk satu kali musim tanam sebesar Rp201.724.000,00 dengan rata-rata pendapatan usahatani setiap responden sebesar Rp4.034.480,00. Rata-rata biaya produksi, penerimaan dan pendapatan dapat dilihat pada Gambar 3.

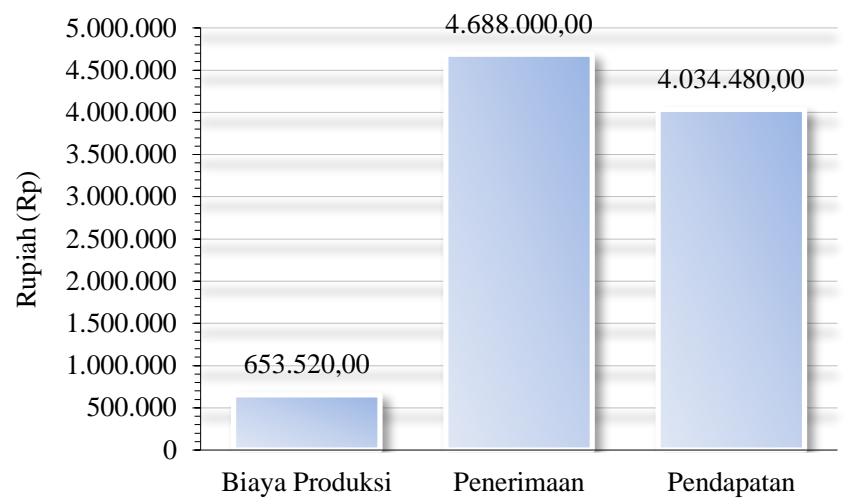

Gambar 3. Rata-rata Pendapatan Usahatani Selada Air

\subsection{Keuntungan Relatif (R/C Ratio)}

Penerimaan total sebesar Rp234.400.000,00 dengan rata-rata penerimaan sebesar Rp4.688.000,00. Total biaya sebesar Rp32.676.000,00 dengan rata-rata sebesar Rp653.520,00 sehingga nilai R/C ratio sebesar 7,103. Secara ekonomis usahatani selada air di desa Popnam menguntungkan sehingga layak untuk dilanjutkan, karena setiap pengeluaran berupa biaya sebesar Rp1,00 akan memberi penerimaan sebesar Rp7,103,00.

\section{Simpulan}

Lahan usahatani yang digarap oleh petani adalah lahan milik sendiri dengan kisaran luas lahan bervariasi antara 3-15 are. Tahapan kegiatan usahatani dimulai dari persiapan lahan, persiapan bibit, penanaman, pemeliharaan (penyiangan, pemupukan dan pengendalian hama penyakit), panen dan pasca panen. Pendapatan usahatani selada air di desa Popnam adalah sebesar Rp201.724.000,00 dengan rata-rata pendapatan usahatani selada air sebesar Rp4.034.480,00. Nilai R/C Ratio sebesar 7,103. Artinya kegiatan usahatani selada air di desa Popnam menguntungkan secara ekonomis dan layak untuk dilanjutkan karena setiap biaya yang dikeluarkan sebesar Rp1,00 akan memberikan penerimaan sebesar Rp7,103,00.

\section{Pustaka}

Hadisapoetro, S. 1973. Pembangunan Pertanian. Yogyakarta: Departemen Ekonomi Pertanian Fakultas Pertanian, Universitas Gadjah Mada.

Haki, M.G. \& Taena, W. 2017. Analisis Pendapatan Usahatani Cabe Rawit Merah di Desa Tapenpah Kecamatan Insana Kabupaten Timor Tengah Utara. AGRIMOR, 2(04): 57-58.

Muhlisah, F. \& Sapta, H. 1997. Sayur dan Bumbu Dapur Berkhasiat Obat. Jakarta: Penebar Swadya.

Nubatonis, A. 2016. Analisis Pendapatan Usahatani Sawi di Desa Humusu Oekolo Kecamatan Insana Utara Kabupaten Timor Tengah Utara. AGRIMOR, 1(01): 1-2.

Opat, E. \& Hutapea, A.N. 2017. Analisis Pendapatan Usahatani Sawi Manis di Kelurahan Oelami, Kecamatan Bikomi Selatan, Kabupaten Timor Tengah Utara. AGRIMOR, 2(03): 33-35.

Pangkalan Ide 2014. Agar Otak Sehat. Jakarta: Elex Media Komputindo.

Pay, Y.A. \& Nubatonis, A. 2017. Analisis Pemasaran Buncis di Desa Oerinbesi Kecamatan Biboki Tanpah Kabupaten Timor Tengah Utara. AGRIMOR, 2(04): $52-54$
Priyadi, S. 2007. Pertumbuhan Dan Produktivitas Selada Air (Nasturtium Officinale) Pada Berbagai Tinggi Genangan Di Desa Kaligiri, Kabupaten Brebes-Jawa Tengah. Skripsi. Bogor: Institut Pertanian Bogor.

Soekartawi 1993. Agribisnis: Teori dan Aplikasinya. Jakarta: Raja Grafindo Persada.

Soekartawi 1995. Analisis Usaha Tani. Jakarta: Universitas Indonesia Press.

Sugiyono 2006. Metode Penelitian Kuantitatif, Kualitatif dan $R \& D$. Bandung: Alfabeta.

Sutrisno, H. 2004. Metodologi Research: Untuk Menulis Laporan, Skripsi, Thesis dan Disertasi. Yogyakarta: Andi Offset.

Tani'i, O. \& Kune, S.J. 2016. Analisis Pendapatan Usahatani Sayur Kangkung di Kelurahan Bansone, Kecamatan Kota Kefamenanu, Kabupaten Timor Tengah Utara. AGRIMOR, 1(04): 72-74. 